\title{
Mineral nutrient status of tree species in relation to environmental factors in the subtropical rain forest of Taiwan
}

\author{
Chia-Chi $\mathrm{Wu}^{\mathrm{a}}$, Chun-Chih Tsui ${ }^{\mathrm{a}}$, Chang-Fu Hseih ${ }^{\mathrm{b}}$, Victor B. Asio ${ }^{\mathrm{c}}$, Zueng-Sang Chen ${ }^{\mathrm{a}, *}$ \\ ${ }^{a}$ Graduate Institute of Agricultural Chemistry, College of Bio-Resources and Agriculture, National Taiwan University, Taipei 106-17, Taiwan \\ ${ }^{\mathrm{b}}$ Institute of Ecology and Evolutionary Biology, College of Life Science, National Taiwan University, Taipei 106-17, Taiwan \\ ${ }^{\mathrm{c}}$ Institute of Tropical Ecology, Leyte State University, Baybay, Leyte 6521-A, Philippines
}

Received 25 August 2005; received in revised form 11 November 2006; accepted 15 November 2006

\begin{abstract}
Until now, the mineral nutrition of rain forest trees is still poorly understood. Very few data are available on the nutrient characteristics of rain forest tree species and the influence of environmental factors especially for subtropical climates. This study evaluated the mineral nutrient status of the dominant tree species and its relation to environmental factors such as elevation, slope, landscape position, and soil nutrient status in a subtropical rain forest of southern Taiwan. Leaf, stem, and wood samples were collected for nutrient analysis from a total of 639 trees belonging to 20 dominant species from 27 contiguous $20 \mathrm{~m} \times 20 \mathrm{~m}$ quadrants along an altitudinal transect ranging from 300 to $480 \mathrm{~m}$. Composite soil samples were likewise collected from the $0-5$ and $5-15 \mathrm{~cm}$ depths in the A horizon in each quadrant for chemical analysis. Soils in the study site ranged from well-developed, acidic with clayey subsoil Typic Paleudult in summit positions, to poorly developed and acidic Typic Dystrudept in backslope positions. Results revealed that leaf nutrient concentration was better correlated with the environmental factors than stem and wood nutrient concentrations. In addition, data showed generally wide concentration ranges for most mineral nutrients except $\mathrm{P}$ and $\mathrm{Cu}$ and most tree species were clustered at the lower end of the concentration ranges indicating they have low nutrient status. Among the macronutrients, $\mathrm{P}$ had the lowest and narrowest foliar concentration $\left(0.25-2.8 \mathrm{~g} \mathrm{~kg}^{-1}\right.$; mean $\left.=0.8\right)$ while for the micronutrients, this was shown by $\mathrm{Cu}\left(3.88-17 \mathrm{mg} \mathrm{kg}{ }^{-1}\right.$; mean $=5.8$ ). A few tree species were observed to accumulate (called "accumulator species") some mineral nutrients like $\mathrm{N}, \mathrm{P}, \mathrm{K}, \mathrm{Ca}, \mathrm{Mg}, \mathrm{Cu}$ and $\mathrm{Zn}$ indicating high absorption capacity for these nutrients. Foliar mineral nutrient concentration of the trees was generally correlated with the environmental factors such as elevation, topographic position, slope, vegetation type, and soil nutrient status. However, the effects were interrelated and difficult to isolate from each other although topographic position, vegetation type, and soil nutrient status appeared to be more related to the mineral nutrient concentration of the trees than the other environmental factors. In particular, plants on the footslope had generally higher concentration of N, P and K than those at the higher elevation of the upper backslope and summit. This suggests that the distribution of tree species in the study site is reflected by their foliar nutrient concentration. P appears to be the most limiting nutrient in the rain forest ecosystem studied although fertilization experiment is needed to verify the apparent $\mathrm{P}$ limitation.
\end{abstract}

(C) 2006 Elsevier B.V. All rights reserved.

Keywords: Mineral nutrient status; Subtropical rainforest; Environmental factors; Soil nutrients

\section{Introduction}

The mineral nutrient status of plants is directly related to their growth and productivity. It is controlled by their genetically fixed nutrient uptake potential, the nutrient availability in the soil, and other environmental factors (Mengel and Kirkby, 2001; Van den Driessche, 1974). For rain forests, the high tree species diversity and soil variability,

\footnotetext{
* Corresponding author. Tel.: +886 22369 8349; fax: +886 223924335 . E-mail address: soilchen@ntu.edu.tw (Z.-S. Chen).
}

changes in slope, elevation, topographic position, and climate interact to affect the mineral nutrition of the trees. The complexity and site specificity of such interaction is probably one reason why the mineral nutrition of rain forest trees is still poorly understood until now. Thus, it is not yet clear which among the environmental factors in a rain forest ecosystem control the nutrition of the trees. Likewise, very little information is available on the relative amounts of nutrients taken up by rain forest trees from the soil.

Previous research has shown that the mineral nutrient concentration in the leaves of tropical rain forest trees varies widely due to high diversity of tree species and environmental 
conditions particularly heterogeneous soil properties (Grubb, 1977; Vitousek and Sanford, 1986; Masunaga et al., 1998a,b). Vitousek and Sanford (1986) suggested that nutrient concentrations in individual tissue of rain forest trees are more likely to reflect the influence of soil fertility. They added that where a single species is found on two soils that differ in soil fertility, foliar nutrient concentrations are usually quite similar. Grubb (1977) observed that tropical mountain forest trees are generally adapted to a relatively poor supply of $\mathrm{N}$ and $\mathrm{P}$ and thus, tend to have low concentrations of these two mineral nutrients. The studies by Masunaga et al. (1998a,b,c) in West Sumatra, Indonesia, provided new insights into the nutrient characteristics of tropical rain forest trees although they did not relate it to the environmental conditions. They found for instance that concentrations of most elements were higher in the leaves than in the bark. They were also able to classify the tree species into accumulators and excluders based on a novel statistical method they employed. They concluded, among other things, that the high variations in the nutritional characteristics of the trees reflect the high species diversity of the study site. We could not find in the literature similar studies especially for subtropical areas that relate the nutrient status of the trees to the environmental factors affecting it.

Information on the mineral nutrition of rain forest tree species is necessary for understanding the response of rain forest ecosystems to natural and anthropogenic perturbations, for the selection of suitable native species for reforestation of degraded areas, and for sustainable forest management. The finding by Nussbaum et al. (1995) that nutrient deficiency is the most important factor limiting early growth of indigenous rain forest trees on degraded soils underscores the need for more information on the mineral nutrition of native tree species to enhance the use of such trees for reforestation purposes.

The objectives of this study were to evaluate the nutrient status of the dominant tree species in the subtropical rain forest of southern Taiwan, and to find out its relation to the environmental factors such as elevation, slope, landscape position, soil $\mathrm{pH}$ and soil available nutrients. These were part of a multidisciplinary long-term ecology research project we started in 1990. Earlier, we reported on the relationship between soil, landscape and vegetation types for a nearby site (Chen et al., 1997) and northern Taiwan (Hsieh et al., 1998), and between soil properties and slope position on the same transect (Tsui et al., 2004).

\section{Materials and methods}

\subsection{Study site}

The study site is located in Nanjenshan Nature Reserve of Kenting National Park in southernmost Taiwan $\left(22^{\circ} 03^{\prime} 37 \mathrm{~N}\right.$, $120^{\circ} 51^{\prime} 10 \mathrm{E}$ ) (Fig. 1). The site was chosen because it was relatively undisturbed with no observable anthropogenic influence and because of its landscape diversity and varying vegetation patterns. Within the short range of $200-400 \mathrm{~m}$ in elevation, there is high biodiversity of vegetation indicating a

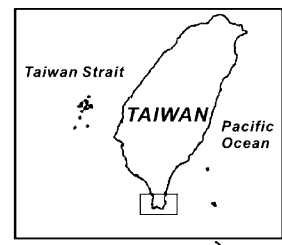

(a)

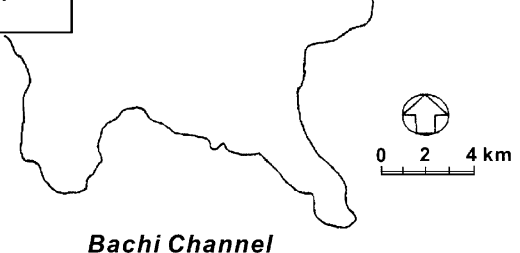

Bachi Channel

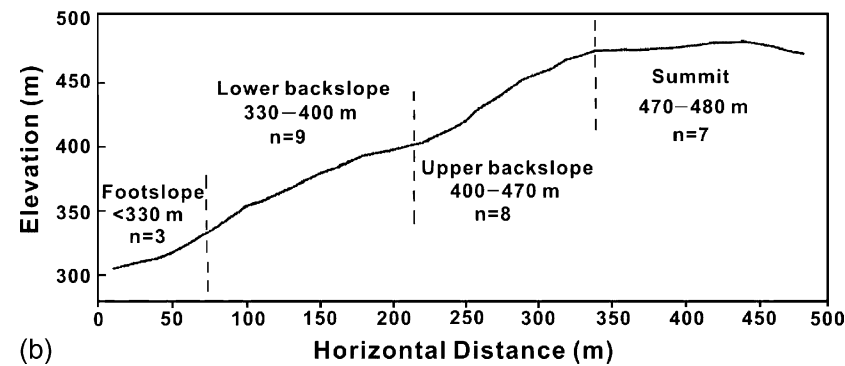

Fig. 1. (a) Geographical location of the long-term ecological research site in Nanjenshan Mountain in southern Taiwan and (b) the geomorphic profile of the study site showing the topographic positions ( $n$ : number of the $20 \mathrm{~m} \times 20 \mathrm{~m}$ sampling plots in slope positions at different elevations).

phenomenon of vegetation compression (Liao, 1995). A transect measuring $450 \mathrm{~m}$ long and $40 \mathrm{~m}$ wide was laid out in 1994 starting at an elevation of $300 \mathrm{~m}$ in the footslope position to $480 \mathrm{~m}$ on the summit of Mt. Nanjenshan. Soils in the site formed from sandstone and shale and range from welldeveloped, acidic with clayey subsoil Typic Paleudult in summit positions, to poorly developed and acidic Typic Dystrudept in backslope and other unstable slope positions (Soil Survey Staff, 1999; Tsui et al., 2004). Climatic data collected from October 1995 to March 2001 from two meteorological stations set up at the altitude of 260 and $470 \mathrm{~m}$ showed no obvious differences in temperature and precipitation at these two elevations. They also showed an annual rainfall ranging from 3250 to $3820 \mathrm{~mm}$, a mean annual air temperature of $22.7^{\circ} \mathrm{C}$ and a mean monthly air temperature of $18{ }^{\circ} \mathrm{C}$ in January to $28.1{ }^{\circ} \mathrm{C}$ in July. Vegetation along the transect consists of 139 free-standing woody species in 91 genera and 49 families, which can be divided into three distinct vegetation types (Liao, 1995). Dominance at the family level also tends to change along the altitudinal gradient. Dominance of Moraceae, Euphorbiaceae, Rubiaceae and Meliaceae decreases with increasing altitude. On the contrary, dominance of Lauraceae, Aquifoliaceae and Fagaceae increases along the altitude. The forest in the footslope is dominated by families found mainly in the tropics while the one on the summit is dominated by families showing northern and eastern Asia affinities. Forest on the backslope or middle portion of the transect represents a transition in structure, floristic composition and habitat. More detailed information on the forest stature is presented in Table 1. 
Table 1

Composition and structure characteristics of the three vegetation types along the altitudinal gradient of the study site

\begin{tabular}{|c|c|c|c|}
\hline & Vegetation type I & Vegetation type II & Vegetation type III \\
\hline Position & Footslope & Backslope & Summit \\
\hline Elevation (m) & $250-330$ & $330-390$ & $390-470$ \\
\hline Slope $\left(^{\circ}\right)$ & $11-39$ & $18-45$ & $0-18$ \\
\hline No. of trees/ha & 1524 & 6660 & 8131 \\
\hline Mean basal area ${ }^{a}\left(m^{2}\right)$ & 15.3 & 7.58 & 5.95 \\
\hline No. of species & 71 & 72 & 100 \\
\hline Major families & Moraceae, Rubiaceae, Euphorbiaceae & Lauraceae, Euphorbiaceae, Aquifoliaceae & Lauraceae, Fagaceae, Aquifoliaceae \\
\hline Dominant species & $\begin{array}{l}\text { Ficus benjamina L., Dysoxylum kuskusense } \\
\text { (Hayata) Kanehira \& Hatusima, } \\
\text { Schefflera octophylla (Endl.) Harms., } \\
\text { Drypetes hieranensis (Hayata) Pax, } \\
\text { Machilus japonica Sieb. \& Zucc. var. } \\
\text { kusanoi (Hayata) Liao, } \\
\text { Psychotria rubra (Lour.) Poir. }\end{array}$ & $\begin{array}{l}\text { Ilex cochinchinensis (Lour.) Loes., } \\
\text { Schefflera octophylla (Endl.) Harms., } \\
\text { D. hieranensis (Hayata) Pax, Turpinia } \\
\text { ternate Nakai, H. formosana Hemsl., } \\
\text { P. rubra (Lour.) Poir }\end{array}$ & $\begin{array}{l}\text { Syzygium euphlebium (Hayata) Mori, } \\
\text { I. cochinchinensis (Lour.) Loes., } \\
\text { Cyclobalanopsis longinux (Hayata) Schott., } \\
\text { Beilschmiedia erythrophloia Hayata, } \\
\text { Castanopsis stellato-spina Hayata, Aucuba } \\
\text { chinensis Benth. }\end{array}$ \\
\hline Characteristic species & $\begin{array}{l}\text { Laportea pterostigma Wedd., F. benjamina } \\
\text { L., Bischofia janavica Blume, Aglaia } \\
\text { elliptifolia Merr. }\end{array}$ & Helicia rengetiensis Masamune & $\begin{array}{l}\text { Cyclobalanopsis championii (Benth.) } \\
\text { Oerst. ex Schott., Osmanthus marginatus } \\
\text { (Champ. ex Benth.) Hemsl., Ilex triflora } \\
\text { Blume var. kanehirai (Yamamoto) S. Y. Hu, } \\
\text { Aucuba chinensis Benth. }\end{array}$ \\
\hline
\end{tabular}

Source: Liao (1995).

a Per 1000 trees.

\subsection{Collection of plant tissue and soil samples}

The transect was divided into 27 contiguous subplots, each measuring $20 \mathrm{~m} \times 20 \mathrm{~m}$, using transits, taps and staid rods. The subplots (sampling plots) were distributed as follows: three in the footslope, nine in the lower backslope, eight in the upper backslope and seven in the summit positions. Vegetation species in each subplot were identified and the diameter at breast height (dbh) was measured for all tree species. From this, 20 dominant tree species from different landscape positions and vegetation types were chosen for tissue sampling. At least 5 trees of each species were chosen in each sampling plot to represent different girth classes $(4,8,12,16$ and $20 \mathrm{~cm} \mathrm{dbh})$ for a total of 639 trees in the entire study site. To collect leaf samples, young and mature healthy leaves were taken from each identified sampling tree and mixed. For branch wood sampling, a branch of about $1 \mathrm{~cm}$ in diameter was taken from each sample tree. Stem wood samples were collected by cutting a portion of the stem (a wedge about $5 \mathrm{~cm}$ in size) of each tree, carefully in order to minimize damage to the tree, at about breast height. All samples were air dried at $65{ }^{\circ} \mathrm{C}$ to constant weight and ground into powder for elemental analysis. Composite soil samples, each coming from four sub-samples, were taken at two soil depths $(0-5$ and $5-15 \mathrm{~cm})$ in the A horizon in each subplot using an auger with a diameter of $8 \mathrm{~cm}$. These samples were air dried and sieved through a $2 \mathrm{~mm}$ sieve.

All plant tissue and soil samplings were carried out from February to August 1999.

\subsection{Chemical analysis}

Elemental concentrations of the powdered leaf and wood samples were measured after wet digestion by $\mathrm{H}_{2} \mathrm{O}_{2} / \mathrm{H}_{2} \mathrm{SO}_{4}$ mixture (Jones and Case, 1990) by atomic absorption spectrophotometry (AAS) for $\mathrm{K}, \mathrm{Ca}, \mathrm{Mg}, \mathrm{Fe}, \mathrm{Mn}, \mathrm{Cu}$, and $\mathrm{Zn}$; by auto sampler (Kjeltec auto sampler 1035 analyzer, Tecator) for N; and P by photometry after color development following the molybdenum blue method (Murphy and Riley, 1962)

For the soil samples, soil properties were analyzed following the methods of USDA-NRCS (Soil Survey Laboratory Staff, 1996) as follows: soil $\mathrm{pH}$ by potentiometric method on soilwater and soil- $\mathrm{KCl}$ solution mixtures in a ratio of 1:1; organic $\mathrm{C}$ by the modified Walkley-Black method; exchangeable $\mathrm{K}$, $\mathrm{Na}, \mathrm{Ca}$ and $\mathrm{Mg}$ by extraction with $1 \mathrm{M}$ ammonium acetate $(\mathrm{pH}$ 7.0) and determined by AAS (Hitachi, 180-30 type); available $\mathrm{Fe}, \mathrm{Mn}, \mathrm{Cu}$ and $\mathrm{Zn}$ by extraction using DTPA-TEA solution ( $\mathrm{pH}$ 5.3) and determined by AAS; available $\mathrm{N}$ by extraction with $4 \mathrm{M} \mathrm{KCl}$ following incubation at $40{ }^{\circ} \mathrm{C}$ for 7 days and then determined by Kjeltec Autosampler System 1035 Analyzer; and available $\mathrm{P}$ and $\mathrm{K}$ by the Bray No. 1 and the Mehlich No. 1 methods, respectively.

\subsection{Statistical analysis}

In order to show the relationships between foliar concentrations of the mineral nutrients and the environmental factors such as elevation, slope, topographic position, vegetation type and soil nutrient status, redundancy analysis (RDA, program CANOCO) (ter Braak, 1990) was carried out. RDA is a linear multivariate technique for relating two sets of variables. To corroborate and support the relationships between the variables obtained by RDA, Pearson's correlation coefficients were calculated between the foliar nutrient concentrations and the environmental factors. Differences in nutrient concentrations among species as well as between topographic positions were tested for significance by one-way analysis of variance (SAS Institute, 1990). 


\section{Results}

\subsection{The distribution pattern and concentrations of mineral nutrients in the trees}

We focus our article on the leaf or foliar concentration of nutrients only since the mineral nutrient concentrations in the stem and branch wood samples were highly variable, showed no clear pattern in terms of distribution in the plants, and were poorly correlated with the environmental factors (data not shown).

Fig. 2 reveals the frequency distribution of the foliar nutrient concentrations of the 639 trees belonging to the 20 dominant species sampled. It shows a generally comparable distribution patterns for most mineral nutrients in that they tend to be distributed at the lower ends of their concentration ranges, which are generally wide except for $\mathrm{P}$ and $\mathrm{Cu}$. In addition, the patterns for the major macronutrients $\mathrm{N}, \mathrm{P}$ and $\mathrm{K}$ show few trees
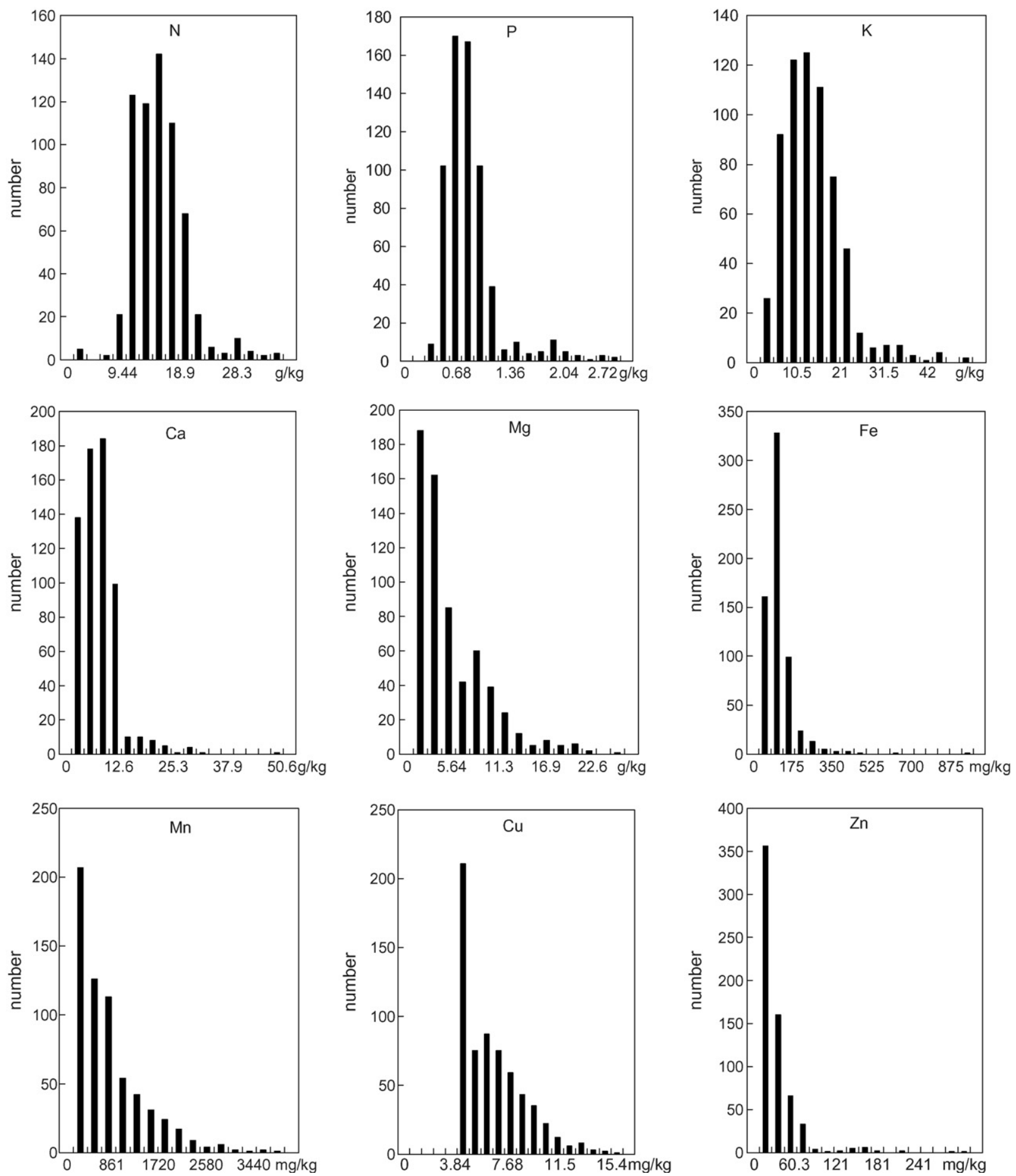

Fig. 2. Frequency distribution of the standard concentrations of mineral nutrients in the leaves of the dominant tree species in the study site. 
occurring at both ends of the concentration ranges. Among the macronutrients, $\mathrm{P}$ had the lowest and narrowest foliar concentration $\left(0.25-2.8 \mathrm{~g} \mathrm{~kg}^{-1}\right.$; mean $\left.=0.8\right)$ while for the micronutrients, this was shown by $\mathrm{Cu}\left(3.88-17.0 \mathrm{mg} \mathrm{kg}^{-1}\right.$; mean $=5.8)($ Table 2$)$. A related pattern was observed when the frequency distribution of the logarithmic-transformed concentrations of the mineral nutrients was plotted (Fig. 3). Most of the mineral nutrients were similar to the log normal distribution pattern except that $\mathrm{Cu}$ and $\mathrm{Zn}$ had abnormally high frequency at low concentration. Several peaks can also be observed for $\mathrm{K}$, $\mathrm{Mg}$ and $\mathrm{Mn}$ : for $\mathrm{K}$ at around 0.6, 1.2 and 1.6, for $\mathrm{Mg}$ at around 1.35 and 2.1, for Mn at around 1.87, 2.55 and 2.89. Such peaks are interpreted to indicate different groups of tree species (Masunaga et al., 1998b).

It is apparent from the patterns presented in Figs. 2 and 3 that the trees may be roughly grouped into: (1) those trees with very low nutrient contents; (2) those with intermediate nutrient contents which are the most abundant trees; (3) those trees with
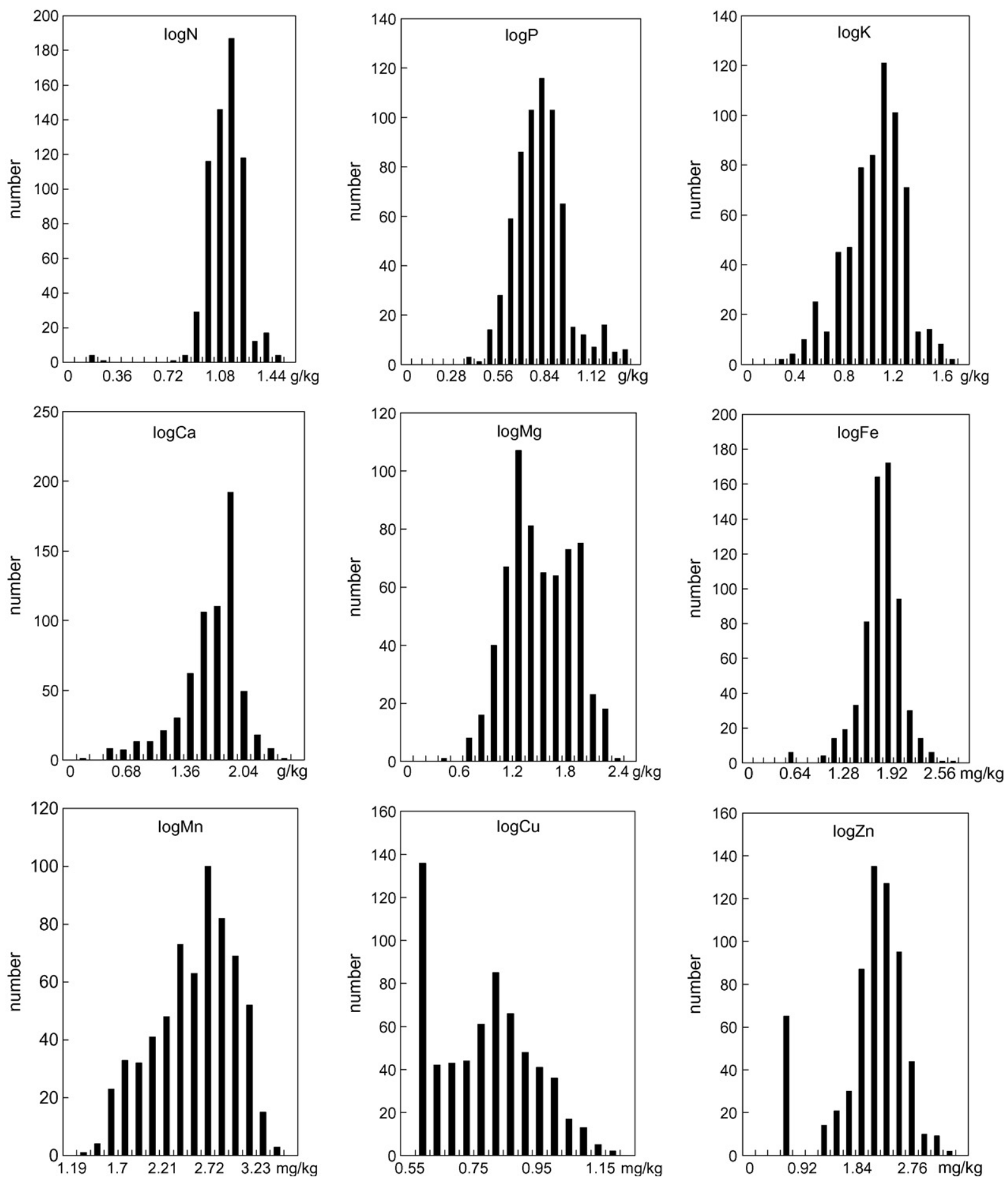

Fig. 3. Frequency distribution of the logarithmic concentrations of mineral nutrients in the leaves of the dominant tree species. 
Table 2

Concentration ranges and mean values of the of mineral nutrients in the leaves of the dominant tree species $(n=639)$

\begin{tabular}{llc}
\hline Mineral nutrient & Concentration range $\left(\mathrm{g} \mathrm{kg}^{-1}\right)$ & Mean \pm S.D. $\left(\mathrm{g} \mathrm{kg}^{-1}\right)$ \\
\hline Nitrogen & $1.24-37.7$ & $15.5 \pm 4.77$ \\
Phosphorus & $0.25-2.80$ & $0.80 \pm 0.38$ \\
Potassium & $1.88-53.8$ & $13.8 \pm 7.86$ \\
Calcium & $0.13-52.3$ & $6.90 \pm 5.09$ \\
Magnesium & $0.22-29.1$ & $5.00 \pm 4.60$ \\
& & \\
Mineral nutrient & Concentration range $\left(\mathrm{mg} \mathrm{kg}^{-1}\right)$ & Mean \pm S.D. $\left(\mathrm{mg} \mathrm{kg}^{-1}\right)$ \\
\hline Iron & $3.79-1010$ & $98.3 \pm 6.7$ \\
Manganese & $22.6-4130$ & $730 \pm 708$ \\
Copper & $3.88-17.0$ & $5.80 \pm 3.73$ \\
Zinc & $0.32-324$ & $27.3 \pm 35.1$ \\
\hline
\end{tabular}

high nutrient concentrations. The latter group is found at the upper end of the concentration range.

Fig. 4 shows the nutrient characteristics of the 20 dominant tree species. It classifies the nutrient concentration of each particular tree species into grades or classes based on the mean value and standard deviation of the logarithmic concentrations for each nutrient according to the method used by Masunaga et al. (1998a,b). The different classes are as follows: (1) the logarithmic nutrient concentration falls below the mean value minus 2 standard deviation ( $<\bar{X}-2$ S.D.); (2) the nutrient concentration falls between $(\bar{X}-2$ S.D. $)$ and $\bar{X}$; (3) the nutrient concentration lies between $\bar{X}$ and $(\bar{X}+2$ S.D.); (4) the nutrient concentration is above $(\bar{X}+2$ S.D. $)$. Tree species whose logarithmic concentration of a nutrient falls below the ( $\bar{X}-2$ S.D.) value is an "excluder" for that particular nutrient, while if above the ( $\bar{X}+2$ S.D. $)$ value, it is an "accumulator" species for that nutrient (Masunaga et al., 1998a,b). As in the frequency distribution analysis, only three classes can be identified. Moreover, a few species were qualified as accumulator species but none as excluder species. The accumulator species included Aglaia elliptifolia and Laportea pterostigma for $\mathrm{N}$; A. elliptifolia, Dysoxylum kuskusense, Ficus benjamina and L. pterostigma for P; A. elliptifolia and L. pterostigma for $\mathrm{K}$; L. pterostigma for $\mathrm{Ca}$ and $\mathrm{Mg}$; D. kuskusense for $\mathrm{Cu}$; and Ilex triflora var. kanehirai for $\mathrm{Zn}$.

\begin{tabular}{|c|c|c|c|c|c|c|c|c|c|c|c|}
\hline Tree species & Vegetation type & $\mathrm{n}$ & $\mathrm{N}$ & $\mathrm{P}$ & K & $\mathrm{Ca} / \mathrm{I}$ & $\mathrm{Mg}$ & $\mathrm{Fe}$ & $\mathrm{Mn}$ & $\mathrm{Cu}$ & $\mathrm{Zn}$ \\
\hline Aglaia elliptifolia & I & 5 & & & & & & & & & \\
\hline Bischofia janavica & I & 8 & & & & & & & & & \\
\hline Dysoxylum kuskusense & I & 12 & & & & & & & & & \\
\hline Ficus benjamina & I & 8 & & & & & & & & & \\
\hline Laportea pterostigma & I & 12 & & & & & & & & & \\
\hline Schefflera octophylla & $\mathrm{I}, \Pi$ & 44 & & & & & & & & & \\
\hline Drypetes hieranensis & $\mathrm{I}, \mathrm{I}, \mathrm{III}$ & 64 & & & & & & & & & \\
\hline Psychotria rubra & $\mathrm{I}, \mathrm{I}, \mathrm{III}$ & 97 & & & & & & & & & \\
\hline Helicia formosana & II & 44 & & & & & & & & & \\
\hline Helicia rengetiensis & II & 4 & & & & & & & & & \\
\hline Turpinia ternata & II & 26 & & & & & & & & & \\
\hline Ilex cochinchinensis & II & 71 & & & & & & & & & \\
\hline Beilschmiedia erythrophloia & III & 33 & & & & & & & & & \\
\hline Castanopsis stellato-spina & III & 10 & & & & & & & & & \\
\hline Aucuba chinensis & III & 57 & & & & & & & & & \\
\hline Cyclobalanopsis championii & III & 29 & & & & & & & & & \\
\hline Cyclobalanopsis longinux & III & 8 & & & & & & & & & \\
\hline ILex triflora var: kanehirai & III & 29 & & & & & & & & & \\
\hline Osmanthus marginatus & III & 26 & & & & & & & & & \\
\hline Syzygium euphlebium & III & 52 & & & & & & & & & \\
\hline \multicolumn{12}{|l|}{ Legend: } \\
\hline : less than $(\bar{X}-2$ S.D. $)$ & \multicolumn{11}{|c|}{$\square$ : from $(\bar{X}$-2S.D. $)$ to $\bar{X}$} \\
\hline : from $\bar{X}$ to $(\bar{X}+2 \mathrm{~S}$ & \multicolumn{11}{|c|}{$\mathbf{q}$ : greater than $(\bar{X}+2$ S.D. $)$} \\
\hline
\end{tabular}

Fig. 4. Nutrient characteristics of the dominant tree species based on four concentration classes or grades. 
Table 3

Comparison of the foliar nutrient concentrations of the 20 dominant tree species

\begin{tabular}{|c|c|c|c|c|c|c|c|c|c|c|c|}
\hline Tree species & $\begin{array}{l}\text { Vegetation } \\
\text { type }\end{array}$ & $n$ & $\begin{array}{l}\mathrm{N} \\
\left(\mathrm{g} \mathrm{kg}^{-1}\right)\end{array}$ & $\begin{array}{l}\mathrm{P} \\
\left(\mathrm{g} \mathrm{kg}^{-1}\right)\end{array}$ & $\begin{array}{l}\mathrm{K} \\
\left(\mathrm{g} \mathrm{kg}^{-1}\right)\end{array}$ & $\begin{array}{l}\mathrm{Ca} \\
\left(\mathrm{g} \mathrm{kg}^{-1}\right)\end{array}$ & $\begin{array}{l}\mathrm{Mg} \\
\left(\mathrm{g} \mathrm{kg}^{-1}\right)\end{array}$ & $\begin{array}{l}\mathrm{Fe} \\
\left(\mathrm{mg} \mathrm{kg}^{-1}\right)\end{array}$ & $\begin{array}{l}\mathrm{Mn} \\
\left(\mathrm{mg} \mathrm{kg}^{-1}\right)\end{array}$ & $\begin{array}{l}\mathrm{Cu} \\
\left(\mathrm{mg} \mathrm{kg}^{-1}\right)\end{array}$ & $\begin{array}{l}\mathrm{Zn} \\
\left(\mathrm{mg} \mathrm{kg}^{-1}\right)\end{array}$ \\
\hline Aglaia elliptifolia & I & 5 & $29.2 \mathrm{~b}$ & $1.98 \mathrm{~b}$ & $34.4 \mathrm{~b}$ & $9.70 \mathrm{bc}$ & $10.2 \mathrm{bc}$ & $48.8 \mathrm{c}$ & 173 def & $8.16 \mathrm{~cd}$ & $72.3 \mathrm{~b}$ \\
\hline Bischofia janavica & $\mathrm{I}$ & 8 & $15.5 \mathrm{hig}$ & $0.99 \mathrm{ed}$ & $19.4 \mathrm{e}$ & $8.64 \mathrm{~cd}$ & $10.5 \mathrm{~b}$ & $69.4 \mathrm{bc}$ & $44.1 \mathrm{f}$ & $4.06 \mathrm{f}$ & $45.6 \mathrm{~cd}$ \\
\hline Dysoxylum kuskusense & $\mathrm{I}$ & 12 & $24.3 \mathrm{c}$ & $1.71 \mathrm{c}$ & $26.8 \mathrm{c}$ & $8.89 \mathrm{c}$ & $9.10 \mathrm{bcd}$ & $79.1 \mathrm{bc}$ & 462 bcde & $12.4 \mathrm{a}$ & $49.7 \mathrm{c}$ \\
\hline Ficus benjamina & $\mathrm{I}$ & 8 & $17.6 \mathrm{ef}$ & $1.72 \mathrm{c}$ & $16.4 \mathrm{fg}$ & $1.06 \mathrm{i}$ & $2.45 \mathrm{hij}$ & $67.2 \mathrm{bc}$ & 78.5 ef & $8.37 \mathrm{bcd}$ & $2.41 \mathrm{~h}$ \\
\hline Laportea pterostigma & $\mathrm{I}$ & 12 & $32.4 \mathrm{a}$ & $2.31 \mathrm{a}$ & $44.5 \mathrm{a}$ & $28.1 \mathrm{a}$ & $19.3 \mathrm{a}$ & $105 \mathrm{bc}$ & 135 def & $9.16 \mathrm{bc}$ & 26.6 defg \\
\hline Schefflera octophylla & I, II & 44 & $16.6 \mathrm{hfg}$ & $1.03 \mathrm{ed}$ & $22.5 \mathrm{~d}$ & $3.06 \mathrm{ghi}$ & $3.42 \mathrm{hij}$ & $89.6 \mathrm{bc}$ & $635 \mathrm{~b}$ & $7.59 \mathrm{~d}$ & $52.4 \mathrm{c}$ \\
\hline Drypetes hieranensis & I-III & 64 & $18.9 \mathrm{ed}$ & 0.92 ef & $14.3 \mathrm{hg}$ & $8.40 \mathrm{~cd}$ & 4.85 efgh & $99.8 \mathrm{bc}$ & 257 cdef & $8.49 \mathrm{bcd}$ & $28.1 \mathrm{def}$ \\
\hline Psychotria rubra & I-III & 97 & $14.6 \mathrm{hi}$ & $0.73 \mathrm{ghi}$ & $13.3 \mathrm{~h}$ & $6.79 \mathrm{cdef}$ & 6.63 defg & $103 \mathrm{bc}$ & $1530 \mathrm{a}$ & $7.45 \mathrm{~d}$ & $25.3 \mathrm{defg}$ \\
\hline H. formosana & II & 44 & $10.1 \mathrm{~lm}$ & $0.50 \mathrm{kl}$ & $3.40 \mathrm{k}$ & $2.69 \mathrm{hi}$ & $1.66 \mathrm{ij}$ & $73.4 \mathrm{bc}$ & $735 \mathrm{~b}$ & $3.95 \mathrm{f}$ & $5.21 \mathrm{gf}$ \\
\hline H. rengetiensis & II & 4 & $8.56 \mathrm{~m}$ & 0.471 & $8.01 \mathrm{ij}$ & $0.50 \mathrm{i}$ & $0.72 \mathrm{j}$ & $47.2 \mathrm{c}$ & 192 cdef & 4.92 ef & $6.27 \mathrm{fgh}$ \\
\hline Turpinia ternate & II & 26 & $19.0 \mathrm{ed}$ & $1.07 \mathrm{~d}$ & $18.5 \mathrm{ef}$ & $3.92 \mathrm{fgh}$ & $2.70 \mathrm{hij}$ & $65.3 \mathrm{bc}$ & $58.7 \mathrm{f}$ & $5.79 \mathrm{e}$ & $6.39 \mathrm{fgh}$ \\
\hline Ilex cochinchinensis & II, III & 71 & $11.5 \mathrm{lk}$ & $0.55 \mathrm{jkl}$ & $13.6 \mathrm{hg}$ & $5.18 \mathrm{efgh}$ & $6.98 \mathrm{def}$ & $96.3 \mathrm{bc}$ & $849 \mathrm{~b}$ & $7.75 \mathrm{~cd}$ & 35.7 cde \\
\hline Beilschmiedia erythrophloia & III & 33 & 18.4 ef & $0.82 \mathrm{fgh}$ & $13.1 \mathrm{~h}$ & $12.1 \mathrm{~b}$ & $3.61 \mathrm{hij}$ & $82.1 \mathrm{bc}$ & $1790 \mathrm{a}$ & 5.52 ef & $11.2 \mathrm{fgh}$ \\
\hline Castanopsis stellato-spina & III & 10 & $14.7 \mathrm{hi}$ & $0.62 \mathrm{ijk}$ & $8.33 \mathrm{ij}$ & $4.24 \mathrm{fgh}$ & $2.33 \mathrm{hij}$ & $234 \mathrm{a}$ & $630 \mathrm{~b}$ & $4.71 \mathrm{ef}$ & $14.3 \mathrm{efgh}$ \\
\hline Aucuba chinensis & III & 57 & $14.4 \mathrm{i}$ & $0.82 \mathrm{gf}$ & 18.0 ef & 7.51 cde & 3.78 ghij & $125 \mathrm{~b}$ & $560 \mathrm{bc}$ & $5.01 \mathrm{ef}$ & $16.8 \mathrm{efgh}$ \\
\hline Cyclobalanopsis championii & III & 29 & $12.4 \mathrm{jk}$ & $0.50 \mathrm{kl}$ & $6.36 \mathrm{j}$ & 5.10 edgh & $1.20 \mathrm{ij}$ & $125 \mathrm{~b}$ & $480 \mathrm{bcd}$ & 4.62 ef & $14.5 \mathrm{efgh}$ \\
\hline Cyclobalanopsis longinux & III & 8 & $20.5 \mathrm{~d}$ & 0.69 hij & $6.96 \mathrm{ij}$ & 5.70 defg & 4.26 fghi & $107 \mathrm{bc}$ & $737 \mathrm{~b}$ & $5.21 \mathrm{ef}$ & $15.5 \mathrm{efgh}$ \\
\hline Ilex triflora var. kanehirai & III & 29 & $17.0 \mathrm{efg}$ & $0.59 \mathrm{ijkl}$ & $7.54 \mathrm{ij}$ & $7.96 \mathrm{de}$ & $4.00 \mathrm{ghi}$ & $128 \mathrm{~b}$ & $1490 \mathrm{a}$ & 4.99 ef & $117 \mathrm{a}$ \\
\hline Osmanthus marginatus & III & 26 & $12.2 \mathrm{jk}$ & $0.57 \mathrm{jkl}$ & $9.82 \mathrm{i}$ & 7.22 cde & $1.96 \mathrm{hij}$ & $62.4 \mathrm{bc}$ & 184 cdef & $9.71 \mathrm{~b}$ & 20.5 efgh \\
\hline Syzygium euphlebium & III & 52 & $13.9 \mathrm{ij}$ & $0.56 \mathrm{jkl}$ & $8.36 \mathrm{ij}$ & $8.19 \mathrm{~cd}$ & 7.43 cde & $93.8 \mathrm{bc}$ & 82.6 ef & 5.14 ef & $5.87 \mathrm{fgh}$ \\
\hline
\end{tabular}

Note: Values followed by different letters within a column are significantly different at the $p=0.05$ level.

Table 3 shows significant differences in the foliar nutrient concentrations of most of the dominant tree species in the site. In general, the nutrient concentrations of the accumulator species were significantly higher than those of the non-accumulator species. Even among the accumulator species, significant differences were also observed. Significantly highest concentrations of macronutrients were shown by L. pterostigma for N, P, K, $\mathrm{Ca}$, and $\mathrm{Mg}$, Castanopsis stellato-spina for $\mathrm{Fe}$, Psychotria rubra, Beilschmiedia erythrophloia and I. triflora var. kanehirai for Mn (not classified as accumulator), D. kuskusense for $\mathrm{Cu}$, and $I$. triflora var. kanehirai for $\mathrm{Zn}$. On the other hand, the genus
Helicia (H. formosana and $H$. rengetiensis) showed significantly lowest concentrations for many mineral nutrients such as $\mathrm{N}, \mathrm{P}, \mathrm{K}$, $\mathrm{Ca}, \mathrm{Mg}$ and $\mathrm{Fe}$ but high $\mathrm{Mn}$ concentration.

\subsection{Relationship between nutrient contents of trees and environmental factors}

The environmental factors we evaluated included slope, elevation, topographic (or landscape) position, vegetation type, and soil nutrient status of the $0-5$ and $5-15 \mathrm{~cm}$ layers in the A horizon like $\mathrm{pH}$; organic carbon; available $\mathrm{N}, \mathrm{P}$ and $\mathrm{K}$;

Table 4

Average values of soil $\mathrm{pH}$ and nutrient status for the two soil depths in the study site

\begin{tabular}{|c|c|c|c|c|c|c|c|c|c|c|c|c|}
\hline \multirow{2}{*}{$\begin{array}{l}\text { Topographic } \\
\text { position }\end{array}$} & \multirow{2}{*}{$\begin{array}{l}\text { Elevation } \\
(\mathrm{m})\end{array}$} & \multirow{2}{*}{$\begin{array}{l}\text { Sample } \\
\text { no. }^{\text {a }}(n)\end{array}$} & \multirow{2}{*}{$\begin{array}{l}\mathrm{pH} \\
\left(\mathrm{H}_{2} \mathrm{O}\right)\end{array}$} & \multicolumn{3}{|l|}{ Available } & \multicolumn{2}{|c|}{ Exchangeable } & \multicolumn{4}{|c|}{ DTPA extractable } \\
\hline & & & & $\begin{array}{l}\mathrm{N} \\
\left(\mathrm{mg} \mathrm{kg}^{-1}\right)\end{array}$ & $\begin{array}{l}\mathrm{P} \\
\left(\mathrm{mg} \mathrm{kg}^{-1}\right)\end{array}$ & $\begin{array}{l}\mathrm{K} \\
\left(\mathrm{mg} \mathrm{kg}^{-1}\right)\end{array}$ & $\begin{array}{l}\mathrm{Ca} \\
\left(\mathrm{mg} \mathrm{kg}^{-1}\right)\end{array}$ & $\begin{array}{l}\mathrm{Mg} \\
\left(\mathrm{mg} \mathrm{kg}^{-1}\right)\end{array}$ & $\begin{array}{l}\mathrm{Fe} \\
\left(\mathrm{mg} \mathrm{kg}^{-1}\right)\end{array}$ & $\begin{array}{l}\mathrm{Mn} \\
\left(\mathrm{mg} \mathrm{kg}^{-1}\right)\end{array}$ & $\begin{array}{l}\mathrm{Zn} \\
\left(\mathrm{mg} \mathrm{kg}^{-1}\right)\end{array}$ & $\begin{array}{l}\mathrm{Cu} \\
\left(\mathrm{mg} \mathrm{kg}^{-1}\right)\end{array}$ \\
\hline \multicolumn{13}{|l|}{$0-5 \mathrm{~cm}$ soil } \\
\hline Summit & $470-480$ & 20 & $4.8 \mathrm{~b}^{+}$ & $152 \mathrm{a}$ & $10.7 \mathrm{~b}$ & $41.1 \mathrm{a}$ & $20.1 \mathrm{~b}$ & $5.96 \mathrm{~b}$ & $28.6 \mathrm{a}$ & $4.51 \mathrm{c}$ & $0.31 \mathrm{a}$ & $\mathrm{ND}^{\mathrm{b}}$ \\
\hline $\begin{array}{l}\text { Upper } \\
\text { Backslpoe }\end{array}$ & $400-470$ & 13 & $4.9 \mathrm{~b}$ & $131 \mathrm{~b}$ & $8.55 \mathrm{a}$ & $38.0 \mathrm{ab}$ & $18.1 \mathrm{~b}$ & $5.91 \mathrm{~b}$ & $21.6 \mathrm{~b}$ & $4.17 \mathrm{c}$ & $0.22 \mathrm{~b}$ & ND \\
\hline $\begin{array}{l}\text { Lower } \\
\text { backslope }\end{array}$ & $330-400$ & 27 & $5.0 \mathrm{~b}$ & $123 \mathrm{~b}$ & $10.6 \mathrm{~b}$ & $30.9 \mathrm{c}$ & $20.0 \mathrm{~b}$ & $5.88 \mathrm{~b}$ & $23.4 \mathrm{~b}$ & $5.95 \mathrm{~b}$ & $0.27 \mathrm{a}$ & ND \\
\hline Footslope & $<330$ & 14 & $5.3 \mathrm{a}$ & $127 \mathrm{~b}$ & $15.2 \mathrm{a}$ & $34.6 \mathrm{bc}$ & $24.2 \mathrm{a}$ & $6.10 \mathrm{a}$ & $13.8 \mathrm{c}$ & $11.1 \mathrm{a}$ & $0.27 \mathrm{a}$ & ND \\
\hline \multicolumn{13}{|l|}{$5-15 \mathrm{~cm}$ soil } \\
\hline Summit & $470-480$ & 20 & $4.8 \mathrm{~b}$ & $100 \mathrm{a}$ & $9.68 \mathrm{~b}$ & $23.5 \mathrm{ab}$ & $10.7 \mathrm{c}$ & $5.29 \mathrm{~b}$ & $25.2 \mathrm{a}$ & $1.80 \mathrm{c}$ & $0.17 \mathrm{a}$ & ND \\
\hline $\begin{array}{l}\text { Upper } \\
\text { backslpoe }\end{array}$ & $400-470$ & 13 & $4.7 \mathrm{~b}$ & $90 \mathrm{~b}$ & $7.03 \mathrm{c}$ & $25.2 \mathrm{a}$ & $9.76 \mathrm{c}$ & $5.16 \mathrm{~b}$ & $20.8 \mathrm{~b}$ & $1.85 \mathrm{c}$ & $0.13 \mathrm{~b}$ & ND \\
\hline $\begin{array}{l}\text { Lower } \\
\text { backslope }\end{array}$ & $330-400$ & 27 & $4.8 \mathrm{~b}$ & $90 \mathrm{~b}$ & $8.92 \mathrm{bc}$ & $20.6 \mathrm{~b}$ & $14.1 \mathrm{~b}$ & $5.37 \mathrm{~b}$ & $20.7 b$ & $4.32 \mathrm{~b}$ & $0.19 \mathrm{a}$ & ND \\
\hline Footslope & $<330$ & 14 & $5.0 \mathrm{a}$ & $92 \mathrm{ab}$ & $12.1 \mathrm{a}$ & $20.4 \mathrm{~b}$ & $19.1 \mathrm{a}$ & $5.81 \mathrm{a}$ & $12.9 \mathrm{c}$ & $9.40 \mathrm{a}$ & $0.20 \mathrm{a}$ & ND \\
\hline
\end{tabular}

a $10 \mathrm{~m} \times 10 \mathrm{~m}$ plot number.

b Not detectable.

+ There is no significant difference with the same letter in a row at the $p=0.05$ level. 


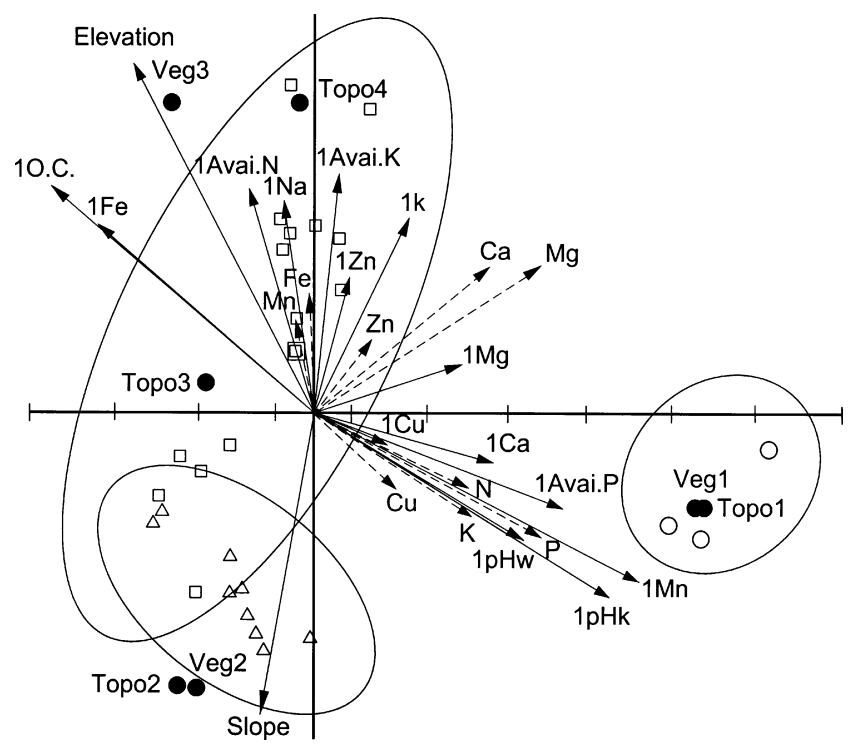

Fig. 5. Ordination diagram based on redundancy analysis (RDA) of environmental variables and foliar nutrient concentration data from Nanjenshan forest. Open circles, open triangles, and open squares represent the sampling plots from footslope (vegetation type I), backslope (vegetation type II), and summit (vegetation type III) positions, respectively. Ellipse encircles each vegetation type. Dashed arrows represent foliar concentrations of various mineral nutrients. Full-lined arrows represent quantitative environmental variables (elevation, slope, and soil nutrient content). Each soil nutrient element is indicated by "1" followed by the chemical symbol. Topographic positions (Topo 1-4) and vegetation types (Veg 1-3) were treated as nominal environmental variables and are represented by filled circles.

exchangeable $\mathrm{K}, \mathrm{Na}, \mathrm{Ca}$ and $\mathrm{Mg}$; and extractable $\mathrm{Fe}, \mathrm{Cu}, \mathrm{Mn}$ and $\mathrm{Zn}$. Our data for the two soil depths revealed very similar relationship between their nutrient status and the foliar nutrient concentrations apparently due to closely similar values of $\mathrm{pH}$ and nutrients at these two soil depths (Table 4). Hence, for the discussion we placed emphasis on the first soil depth $(0-5 \mathrm{~cm})$ only. It can be seen also in Table 4 that the soil in the study site is very acidic and generally contains low mineral nutrients.

The RDA diagram (Fig. 5) shows the relationship between the leaf nutrient concentrations of the trees and the environmental variables such as elevation, slope, topographic position, vegetation type, and soil nutrient status. Each leaf nutrient element/environmental variable is represented by an arrow, which roughly points in the direction of maximum variation of that element/variable across the diagram. The longer the arrows the higher the importance of the nutrient/environmental variable for the distribution of the data. For nominal variables (topographic position and vegetation type), each category is represented in the diagram by a point at the centroid of the sampling plots belonging to that category. The position of a nutrient element relative to an environmental variable or a centroid indicates how strongly the nutrient element is associated with that particular variable. In Fig. 5, the first two RDA axes accounted for $85 \%$ of the variation in leaf nutrient content and associated environmental variables. Three groups of trees can be distinguished along the two main axes of the diagram, and this is supported by the results presented in Table 5 and Fig. 4. The first axis, which explains $56 \%$ of the total variance, separates the footslope plots in the lower right quadrant from the backslope and summit plots on the left side of the diagram. Leaves of the footslope trees generally have higher concentration of macronutrients than those from the backslope and summit. The environmental variables best correlated with the first ordination axis include vegetation type, topographic position and soil properties particularly organic carbon, available $\mathrm{P}$, extractable $\mathrm{Fe}$ and $\mathrm{Mn}$, and $\mathrm{pH}$. Along the second axis, samples from the summit can be distinguished from those from the backslope position. The second ordination axis is strongly correlated with elevation, slope, topographic position, vegetation type and soil nutrients particularly available $\mathrm{N}$ and $\mathrm{K}$, exchangeable $\mathrm{K}$ and $\mathrm{Na}$ as well as organic carbon. For the micronutrients, however, much higher leaf concentrations of Fe and Mn were observed in the upper topographic position particularly the summit than in the lower positions of backslope and footslope. Only minor variations were observed for $\mathrm{Cu}$ and $\mathrm{Zn}$.

Table 6 presents the Pearson's correlation coefficients between leaf nutrient concentrations and environmental factors. It shows significant $(p<0.001)$ positive association between foliar $\mathrm{N}, \mathrm{P}$ and $\mathrm{K}$ concentrations and soil $\mathrm{pH}$, available $\mathrm{P}$ and extractable $\mathrm{Mn}$ but negative association with elevation, topographic position, vegetation type and organic carbon. Foliar N was negatively correlated $(p<0.001)$ with available soil $\mathrm{N}$ and organic carbon, while no relationship was found between foliar $\mathrm{K}$ and soil exchangeable $\mathrm{K}$. $\mathrm{Ca}$ and $\mathrm{Mg}$ were positively correlated $(p<0.001)$ with exchangeable $\mathrm{Ca}$ and $\mathrm{Mg}$ but negatively correlated with slope. Ca also showed positive relationship ( $p<0.01$ ) with vegetation type, $\mathrm{pH}$ and a few other elements. Foliar Fe was positively correlated $(p<0.001)$ with elevation, topographic position, vegetation type and to a lesser degree $(p<0.01)$ with extractable soil Fe and a few other elements. Foliar Mn was positively correlated $(p<0.001)$ with elevation and vegetation type but negatively with extractable soil $\mathrm{Mn}$ while $\mathrm{Cu}$ was negatively correlated $(p<0.001)$ with elevation, topography, vegetation type and

Table 5

Relationships between foliar nutrient concentrations of the tree species and topographic position and elevation

\begin{tabular}{|c|c|c|c|c|c|c|c|c|c|c|c|}
\hline $\begin{array}{l}\text { Topographic } \\
\text { position }\end{array}$ & $\begin{array}{l}\text { Elevation } \\
(\mathrm{m})\end{array}$ & No. & $\begin{array}{l}\mathrm{N} \\
\left(\mathrm{g} \mathrm{kg}^{-1}\right)\end{array}$ & $\begin{array}{l}\mathrm{P} \\
\left(\mathrm{g} \mathrm{kg}^{-1}\right)\end{array}$ & $\begin{array}{l}\mathrm{K} \\
\left(\mathrm{g} \mathrm{kg}^{-1}\right)\end{array}$ & $\begin{array}{l}\mathrm{Ca} \\
\left(\mathrm{mg} \mathrm{kg}^{-1}\right)\end{array}$ & $\begin{array}{l}\mathrm{Mg} \\
\left(\mathrm{mg} \mathrm{kg}^{-1}\right)\end{array}$ & $\begin{array}{l}\mathrm{Fe} \\
\left(\mathrm{mg} \mathrm{kg}^{-1}\right)\end{array}$ & $\begin{array}{l}\mathrm{Mn} \\
\left(\mathrm{mg} \mathrm{kg}^{-1}\right)\end{array}$ & $\begin{array}{l}\mathrm{Zn} \\
\left(\mathrm{mg} \mathrm{kg}^{-1}\right)\end{array}$ & $\begin{array}{l}\mathrm{Cu} \\
\left(\mathrm{mg} \mathrm{kg}^{-1}\right)\end{array}$ \\
\hline Summit & $470-480$ & 182 & $14.3 \mathrm{c}^{+}$ & $0.649 \mathrm{c}$ & $11.4 \mathrm{c}$ & $8.61 \mathrm{~b}$ & $6.94 \mathrm{~b}$ & $123 \mathrm{a}$ & $835 \mathrm{a}$ & $30.2 \mathrm{a}$ & $6.00 \mathrm{c}$ \\
\hline Upper backslope & $400-470$ & 198 & $14.7 \mathrm{bc}$ & $0.693 \mathrm{c}$ & $11.9 \mathrm{c}$ & $6.14 \mathrm{c}$ & $3.69 \mathrm{c}$ & $97.1 \mathrm{~b}$ & 829 a & $19.0 \mathrm{~b}$ & $6.55 \mathrm{bc}$ \\
\hline Lower backslope & $330-400$ & 171 & $15.5 \mathrm{~b}$ & $0.786 \mathrm{~b}$ & $14.7 \mathrm{~b}$ & $3.93 \mathrm{~d}$ & $2.18 \mathrm{~d}$ & $81.6 \mathrm{~b}$ & $587 \mathrm{~b}$ & $28.6 \mathrm{a}$ & $6.77 \mathrm{~b}$ \\
\hline Footslope & $<330$ & 88 & $19.6 \mathrm{a}$ & $1.33 \mathrm{a}$ & $21.3 \mathrm{a}$ & $10.7 \mathrm{a}$ & $9.70 \mathrm{a}$ & $82.6 \mathrm{~b}$ & $563 \mathrm{~b}$ & $34.3 \mathrm{a}$ & $7.96 \mathrm{a}$ \\
\hline
\end{tabular}

${ }^{+}$There is no significant difference with the same letter in a row at the $p=0.05$ level. 


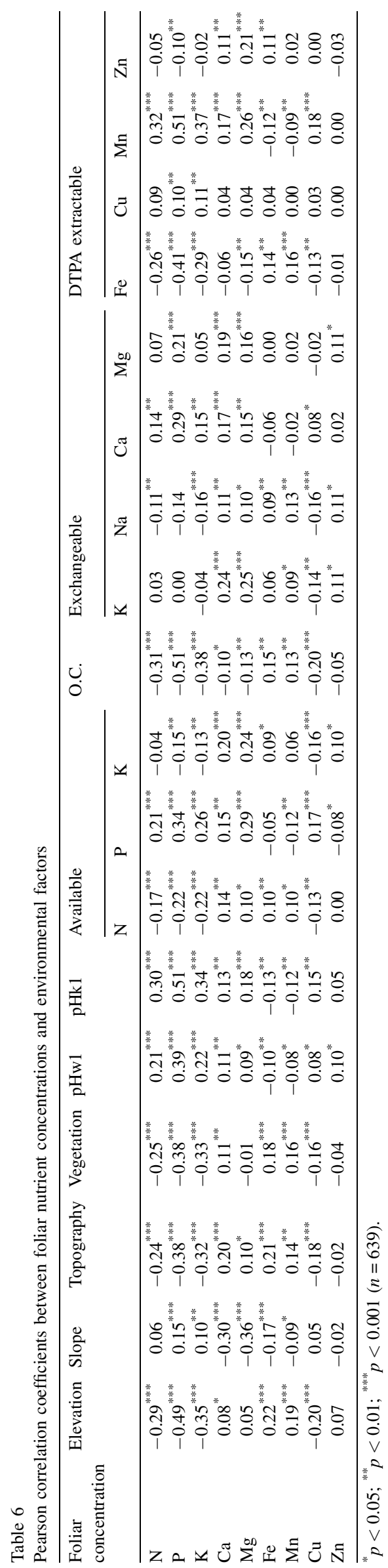

organic carbon but not with extractable soil $\mathrm{Cu}$. $\mathrm{Zn}$ was not related to most environmental factors including extractable $\mathrm{Zn}$ in the soil.

\section{Discussion}

Because of the difficulty of collecting leaf samples from large trees in the rain forest, we collected, in addition to the leaf samples, other plant parts like stems and branch woods for nutrient analysis. Our results indicate that leaf analysis was better than stem and branch wood analysis due to high variability of the results of the latter; they did also not show correlations with the nutrient concentrations in the leaves as well as with the environmental factors. This agrees with recent reports indicating the value of foliar analysis for the assessment of the nutritional status of forest trees (Drechsel and Zech, 1991; Mengel and Kirkby, 2001). The leaf is the focal point of many plant functions and is a relatively sensitive indicator for mineral nutrients (Van den Driessche, 1974). Vitousek and Sanford (1986) suggested that data on nutrient accumulation in leaves of plants on different sites can be useful in comparing nutrient status in different species and soils.

When we compare the mean values of nutrient concentrations from this study with those reported for other tropical rain forests (e.g. Grubb, 1977; Vitousek and Sanford, 1986; Masunaga et al., 1998a,b,c), it turns out that our values are in close agreement especially with those of generally comparable geology and soil conditions. This implies that it is possible to compare the nutrient status of rain forests with comparable environmental conditions despite great differences in species composition. This will allow establishment of optimal and deficiency levels of nutrients in rain forest trees, which until now are not yet clearly delineated (Brunck, 1987; Drechsel and Zech, 1991).

The tendency for the foliar nutrient concentrations in most tree species to occur at the lower end of their observed ranges can be ascribed to the low fertility of the soil implying that soil directly influences the nutrient contents of the trees. It also suggests that the plants are able to adapt to the low nutrient status of the soil by absorbing less. Chapin (1980) reported that slow growing wild plant species characteristics of low fertility soils usually exhibit a low absorption of nutrients. Tropical forests on little fertile sites have low nutrient concentrations and efficient nutrient cycling associated with nutrient limitation in forest ecosystems (Chapin et al., 1986). Ecologists consider such low nutrient content as a defense mechanism by the tropical rain forest trees against attack by herbivores the rate of which has been recently found high in tropical rain forest ecosystems (Coley and Barone, 1996).

Using frequency distributions of elements for rain forest trees from Indonesia (Masunaga et al., 1998b,c) were able to group the tree species into accumulators and excluders. In this study, we were able to show that the tree species could be grouped based on their nutrient status. In addition, we were able to identify five tree species, which have the ability to absorb relatively high amounts (called accumulator species) of $\mathrm{N}$ (two species), $\mathrm{P}$ (four species), $\mathrm{K}$ (two species), $\mathrm{Ca}$ and $\mathrm{Mg}$ (one 
species), $\mathrm{Cu}$ (one species) and $\mathrm{Zn}$ (one species). The ability of one species, L. pterostigma, to accumulate all the macronutrients is interesting. Except for I. triflora, which accumulates $\mathrm{Zn}$, all tree species, which have accumulative characteristics belonged to the first vegetation type found in the footslope position. The possible nutrient accumulation in the footslope does not fully explain the high nutrient uptake by some tree species since only $\mathrm{P}, \mathrm{Ca}, \mathrm{Mg}$ and $\mathrm{Mn}$ were found highest in the footslope while available $\mathrm{N}$ and $\mathrm{K}$, exchangeable $\mathrm{Na}$ and available Fe were found highest on the summit (Tsui et al., 2004) where no accumulator species were observed except one for $\mathrm{Zn}$. The ability of these species to accumulate some mineral nutrients is probably genetically controlled and thus can be ascribed to the influence of species. Grubb (1977) suggested that the selective uptake system in the plant roots has more effect than the leaf anatomy on the concentration of several mineral elements. On the other hand, the genus Helicia with very low concentration of nutrients may be tolerant to such site conditions and are thus considered to be good species for reforestation. The absorption mechanisms of these tree species (those which can absorb high amounts and those which absorb very little) are scientifically interesting and deserve further studies.

The very low concentration of $\mathrm{P}$ in the trees may be attributed to the low $\mathrm{P}$ availability in the soil. But the narrow concentration range in the trees implies low nutrient absorption and requirement by the rainforest trees regardless of species. $P$ is known to be the most limiting nutrient in many tropical forest soils (e.g. Richards, 1996; Tiessen, 1998; Zikeli et al., 2000; Susaya and Asio, 2005) and has been hypothesized to limit the productivity of tropical rain forests (Vitousek, 1984; Tanner et al., 1998; Wardle et al., 2004). Our results tend to support this hypothesis.

The effects of the geomorphic factors are interrelated and difficult to isolate one from the other. Slope is also related since it varies in different topographic positions. It is relatively flat on the footslope and summit but more inclined on backslope. As a result, soil properties and nutrient status vary greatly. Probably in response to these variations in environmental conditions, vegetation is also different in terms of composition from the footslope to the summit (Hsieh et al., 1998). Nevertheless, it appears that topographic position, vegetation type and soil nutrient status had greater effect on the nutrient concentration of the trees. The latter factor, however, was true for some nutrients only.

The general tendency for the trees to be clustered into groups based on their nutrient concentrations seems to explain the natural distribution of the trees in the landscape into three types. However, it is not clear whether this was really due to nutrients or other geomorphic factors like topographic position (climate has been found to be generally uniform in the transect, hence it is not considered here). We suggest two possible explanations: (a) the distribution of the tree species was influenced by topographic position and their nutrient concentrations are but mere reflection of the fertility of the habitat where they are growing, and (b) the topographic position influenced the nutrient status of the soil particularly for some critical nutrients like $\mathrm{P}$, which in turn affected the kind of plant species that would grow in a particular position. The latter is supported by our earlier findings from a nearby site that soil nutrient status partly controlled the distribution of the vegetation in the landscape (Chen et al., 1997).

The relationship between nutrient concentrations in leaves and soils, although generally significant, is complex. For instance, foliar $\mathrm{P}, \mathrm{Ca}, \mathrm{Mg}$ and $\mathrm{Fe}$ were correlated with soil contents while $\mathrm{N}, \mathrm{K}, \mathrm{Mn}$ and $\mathrm{Cu}$ were not. This suggests that leaf nutrient concentrations of trees are affected by many factors as has been reported previously (Grubb, 1977; Vitousek and Sanford, 1986; Pritchett and Fisher, 1987). We also suggest that the nutrient content of the soil at a given time may not truly reflect the foliar nutrient concentration since the trees are slowgrowing and the amounts of nutrients in the leaves represent an accumulation over a certain period of time. Chapin (1980) reported that little fertile soils are most successfully exploited by stress-tolerant species whose inherently low growth rates can be adequately maintained by their low capacities for photosynthesis and nutrient absorption. The annual nutrient requirements of these species are low because of slow rate of tissue production and low nutrient loss rates through both senescence and leaching.

\section{Acknowledgement}

We would like to thank the National Science Council of the Republic of China for financially supporting this research under Contract No. NSC-89-2621-B002-020.

\section{References}

Brunck, F., 1987. Tropical forest species. In: Martin-Prevel, P., Gagnard, J., Gautier, P. (Eds.), Plant Analysis as a Guide to the Nutrient Requirements of Temperate and Tropical Crops. Lavoisier Publ, Paris, pp. 479-486.

Chapin III, F.S., 1980. The mineral nutrition of wild plants. Ann. Rev. Ecol. Syst. 11, 233-260.

Chapin III, F.S., Vitousek, P.M., Van Cleve, K., 1986. The nature of nutrient limitation in plant communities. Am. Nat. 127, 48-58.

Chen, Z.S., Hsieh, C.F., Jiang, F.Y., Hsieh, T.H., Sun, I.F., 1997. Relations of soil properties to topography and vegetation in subtropical rain forest in southern Taiwan. Plant Ecol. 132, 229-241.

Coley, P.D., Barone, J.A., 1996. Herbivory and plant defenses in tropical forests. Ann. Rev. Ecol. Syst. 27, 305-335.

Drechsel, P., Zech, W., 1991. Foliar nutrient levels of broad-leaved tropical trees: a tabular review. Plant Soil 131, 29-46.

Grubb, P.J., 1977. Control of forest growth and distribution on wet tropical mountains: with special reference to mineral nutrition. Ann. Rev. Ecol. Syst. 8, 83-107.

Hsieh, C.F., Chen, Z.S., Hsu, Y.M., Yang, K.C., Hsieh, T.H., 1998. Altitudinal zonation of evergreen broad-leaved forest on Mount Lopei, Taiwan. J. Veg. Sci. 9, 201-212.

Jones, J.B., Case, V.W., 1990. Sampling, handling, and analyzing plant tissue samples. In: Westerman, R.L. (Ed.), Soil Testing and Plant Analysis. 3rd ed. Soil Science Society of America, Inc., Madison, pp. 389-420.

Liao, C.C., 1995. Altitudinal variation in composition, structure, diversity and distribution pattern of the subtropical rain forest in Nanjenshan. Master Thesis, Graduate Institute of Botany, National Taiwan University, Taiwan (in Chinese, with English abstract).

Masunaga, T., Kubota, D., William, U., 1998a. Spatial distribution pattern of trees in relation to soil edaphic status in tropical rain forest in west Sumatra, Indonesia. I. Distribution of accumulation. Tropics 7, 209-222. 
Masunaga, T., Kubota, D., Hotta, M., Wakatsuki, T, 1998b. Nutritional characteristics of mineral elements in leaves of tree species in tropical rain forest, west Sumatra, Indonesia. Soil Sci. Plant Nutr. 44, 315-329.

Masunaga, T., Kubota, D., Hotta, M., Shinmura, Y., Wakatsuki, T., 1998c. Distribution characteristics of mineral elements in trees of tropical rain forest, West Sumatra, Indonesia. In: Schulte, A., Ruhiyat, D. (Eds.), Soil of Tropical Forest Ecosystems. Springer, Heidelberg, pp. 168-174.

Mengel, K., Kirkby, E.A., 2001.In: Principles of Plant Nutrition. 5th ed. Kluwer Academic Publishers, Dordrecht, p. 849.

Murphy, J., Riley, J.P., 1962. A modified single solution for determination of phosphate in nature waters. Anal. Chem. Acta 27, 31-36.

Nussbaum, R., Anderson, J., Spencer, T., 1995. Factors limiting the growth of indigenous tree seedlings planted on degraded rain forest soils in Sabah, Malaysia. For. Ecol. Manage. 74, 149-159.

Pritchett, W.L., Fisher, R.F., 1987.In: Properties and Management of Forest Soils. 2nd ed. John Wiley and Sons, New York, p. 494.

Richards, P.W., 1996.In: The Tropical Rain Forest. 2nd ed. Cambridge University Press, p. 575.

SAS Institute, 1990. SAS/STAT User's Guide, Version 6, 4th ed. SAS Institute, Cary, NC.

Soil Survey Laboratory Staff, 1996. Soil Survey Laboratory Methods Manual. Soil Survey Investigations Report, vol. 42. National Soil Survey Center, Lincoln, NE, Version 3.0, USDA-NRCS.

Soil Survey Staff, 1999. Soil Taxonomy: A Basic System of Soil Classification for Making and Interpreting Soil Surveys. USDA-NRCS, Agricultural Handbook, 2nd ed., vol. 436. U.S Gov. Print Office, Washington, DC.
Susaya, J.P., Asio, V.B., 2005. Status of phosphorus in the rain forest of Mt. Pangasugan, Leyte, Philippines. Ann. Trop. Res. 27, 70-82.

Tanner, E.V.J., Vitousek, P.M., Cuevas, E., 1998. Experimental investigation of nutrient limitation of forest growth on wet tropical mountains. Ecology 79, 10-22.

ter Braak, C.J.F., 1990. CANOCO-A FORTRAN program for canonical community ordination by [partial] [detrended] [canonical] correspondence analysis, principal components analysis and redundancy analysis (Version 3.10) Agricultural Mathematics Group, Wageningen.

Tiessen, H., 1998. Resilience of phosphorus transformations in tropical forest and derived ecosystems. In: Schulte, A., Ruhiyat, D. (Eds.), Soil of Tropical Forest Ecosystems. Springer, Heidelberg, pp. 92-98.

Tsui, C.C., Chen, Z.S., Hsieh, C.F., 2004. Relationships between soil properties and slope position in a lowland rain forest of southern Taiwan. Geoderma 123, 131-142.

Van den Driessche, R., 1974. Prediction of mineral nutrient status of trees by foliar analysis. Bot. Rev. 40, 347-395.

Vitousek, P.M., 1984. Litterfall, nutrient cycling and nutrient limitation in tropical forests. Ecology 65, 285-298.

Vitousek, P.M., Sanford, R.L., 1986. Nutrient cycling in moist tropical forests. Ann. Rev. Ecol. Syst. 17, 137-167.

Wardle, D.A., Walker, L.R., Bardgett, R.D., 2004. Ecosystem properties and forest decline in contrasting long-term chronosequences. Science 305, 509 513

Zikeli, S., Asio, V.B., Jahn, R., 2000. Nutrient characteristics of soil in the rain forest of Mt. Pangasugan, Leyte, Philippines. Ann. Trop. Res. 22, 78-88. 